\title{
Evaluation of the secretion and release of vascular endothelial growth factor from two-dimensional culture and three-dimensional cell spheroids formed with stem cells and osteoprecursor cells
}

\author{
Hyunjin Lee ${ }^{A-F}$, Sung-II Lee ${ }^{A-F}$, Youngkyung Ko ${ }^{A-F}$, Jun-Beom Park ${ }^{A-F}$ \\ Department of Periodontics, College of Medicine, Catholic University of Korea, Seoul, the Republic of Korea \\ A - research concept and design; $\mathrm{B}$ - collection and/or assembly of data; $\mathrm{C}$ - data analysis and interpretation; \\ $D$ - writing the article; $E$ - critical revision of the article; $F$ - final approval of the article
}

Address for correspondence

Jun-Beom Park

E-mail:jbassoonis@yahoo.co.kr

\section{Funding sources}

This research was supported by the Basic Science Research Program through the National Research Foundation of Korea (NRF) funded by the Ministry of Science, Information and Communication

Technology \& Future Planning

(NRF-2017RTA1A1A05001307).

Conflict of interest

None declared

Received on 0ctober 26, 2016

Reviewed on January 19, 2017

Accepted on April 26, 2017

\begin{abstract}
Background. Co-culture has been applied in cell therapy, including stem cells, and has been reported to give enhanced functionality.

Objectives. In this study, stem-cell spheroids were formed in concave micromolds at different ratios of stem cells to osteoprecursor cells, and the amount of secretion of vascular endothelial growth factor (VEGF) was evaluated.
\end{abstract}

Material and methods. Gingiva-derived stem cells and osteoprecursor cells in the amount of $6 \times 105$ were seeded on a 24-well culture plate or concave micromolds. The ratios of stem cells to osteoprecursor cells included: 0:4 (group 1), 1:3 (group 2), 2:2 (group 3), 3:1 (group 4), and 4:0 (group 5).

Results. The morphology of cells in a 2-dimensional culture (groups 1-5) showed a fibroblast-like appearance. The secretion of VEGF increased with the increase in stem cells, and a statistically significant increase was noted in groups 3, 4 and 5 when compared with the media-only group $(p<0.05)$. Osteoprecursor cells formed spheroids in concave microwells, and no noticeable change in the morphology was noted with the increase in stem cells. Spheroids containing stem cells were positive for the stem-cell markers SSEA-4. The secretion of VEGF from cell spheroids increased with the increase in stem cells.

Conclusions. This study showed that cell spheroids formed with stem cells and osteoprecursor cells with different ratios, using microwells, had paracrine effects on the stem cells. The secretion of VEGF increased with the increase in stem cells. This stem-cell spheroid may be applied for tissue-engineering purposes.

Key words: vascular endothelial growth factor, osteoblast, co-culture techniques, cellular spheroids, stem cell research

DOI

10.17219/acem/70789

Copyright

Copyright by Author(s)

This is an article distributed under the terms of the

Creative Commons Attribution Non-Commercial License

(http://creativecommons.org/licenses/by-nc-nd/4.0/) 


\section{Introduction}

Co-culture has been applied in cell therapy, including stem cells, and has been reported to give enhanced functionality. Spheroids formed with primary hepatocytes and hepatic stellate cells showed a higher secretion of albumin than mono-culture hepatospheres. ${ }^{1}$ Additionally, the enzymatic activity of co-cultured heterospheres was higher than the activity of a mono-culture. ${ }^{1}$ Primary pancreatic islets and hepatocytes were applied as spheroids for the 3 -dimensional co-culture model. ${ }^{2}$ It was shown that the 2 different types of cells supported each other's functionality when compared with a mono-culture.

Our group isolated and characterized human mesenchymal stem cells from the gingiva. ${ }^{3}$ Gingiva-derived stem cells have been suggested as candidates in the tissue-engineering field. ${ }^{4}$ In this study, stem-cell spheroids were formed in concave micromolds at different ratios of stem cells to osteoprecursor cells, and the amount of secretion of vascular endothelial growth factor (VEGF) was evaluated. To the best of the authors' knowledge, this report is the first to evaluate the secretion of VEGF from cell spheroids formed with human gingiva-derived stem cells and osteoprecursor cells.

\section{Material and methods}

\section{Isolation and culturing of gingiva-derived stem cells}

Gingiva-derived stem cells were obtained using a previously reported method. ${ }^{4}$ The Institutional Review Board of Seoul St. Mary's Hospital, College of Medicine, Catholic University of Korea approved this study (KC11SISI0348). All participants signed informed consent.

Gingival tissues were de-epithelialized, minced into 1-2 $\mathrm{mm}^{2}$ fragments and digested in an alpha-modified, minimal essential medium ( $\alpha$-MEM; Gibco, Grand Island, USA) containing dispase ( $1 \mathrm{mg} / \mathrm{mL}$; Sigma-Aldrich, St. Louis, USA) and collagenase IV (2 mg/mL; SigmaAldrich). The cells were incubated in a humidified incubator at $37^{\circ} \mathrm{C}$. The non-adherent cells were washed with phosphate-buffered saline (PBS) (Welgene, Daegu, South Korea) and replaced with a fresh medium every 2-3 days.

\section{Co-culture of gingiva-derived stem cells and osteoprecursor cells}

Gingiva-derived stem cells and murine calvarial osteoprecursor cells (MC3T3-E1) (ATCC, Manassas, USA) in the amount of $6 \times 10^{5}$ were seeded on a 24 -well culture plate and grown with a growth medium $\alpha$-MEM. The ratios of stem cells to osteoprecursor cells included: 0:4 (group 1), 1:3 (group 2), 2:2 (group 3), 3:1 (group 4), and 4:0 (group 5).

\section{Formation of cell spheroids with human gingiva-derived stem cells and osteoprecursor cells}

Stem-cell spheroids were formed in polydimethylsiloxane-based concave micromolds (Prosys ${ }^{\circledR}$ StemFit 3D; Prodizen Inc., Seoul, South Korea) of a diameter of $600 \mu \mathrm{m}$ (Fig. 1). Gingiva-derived stem cells and MC3T3-E1 cells in the amount of $6 \times 10^{5}$ were at the ratios of 0:4 (group 1), 1:3 (group 2), 2:2 (group 3), 3:1 (group 4), and 4:0 (group 5). Cell aggregation and cell-spheroid formation were observed under an inverted microscope (Leica DM IRM; Leica Microsystems, Wetzlar, Germany).

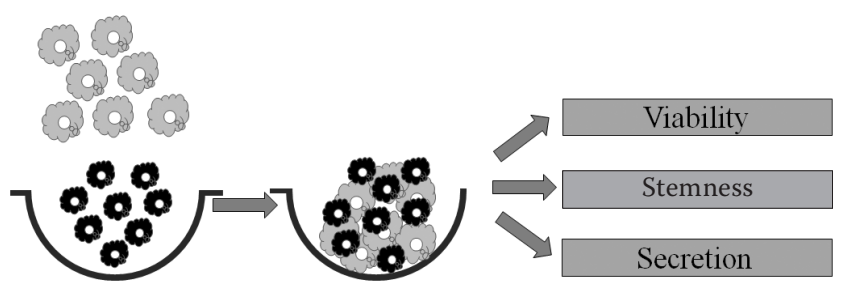

Fig. 1. Schematic illustration of the study using gingival-derived stem cells

\section{Determination of cell viability}

The viability of the cell spheroids was analyzed qualitatively by a Live/Dead Kit assay (Molecular Probes, Eugene, USA) on day 3. The cell spheroids were washed twice with PBS, followed by suspension in $1 \mathrm{~mL}$ of $\alpha$-MEM, containing $2 \mu \mathrm{L}$ of $50 \mathrm{mM}$ calcein acetoxymethyl ester working solution and $4 \mu \mathrm{L}$ of $2 \mathrm{mM}$ ethidium homodimer-1, for $15 \mathrm{~min}$ at room temperature. The spheroids stained with calcein acetoxymethyl ester and ethidium homodimer-1 were observed under a confocal laser microscope (LSM800 with Airyscan; Carl Zeiss, Jena, Germany). The viable cells produced intense, uniform, green fluorescence; dead cells showed red fluorescence with this assay.

\section{Evaluation of maintenance of expression of stem cell markers}

The spheroids were retrieved on day 3 to evaluate the expression of stem cell markers. The spheroids were incubated with human SSEA-4 (Clone MC-813-70) conjugated to NHL493 (green) and human TRA-1-60(R) (Clone TRA1-60) conjugated to NL557 (red) (R\&D Systems, Minneapolis, USA) after dilution to $1 \times$ concentration. The spheroids were visualized under a confocal laser microscope (LSM800 with Airyscan; Carl Zeiss). These antibodies were used as positive markers of human stem cells. 

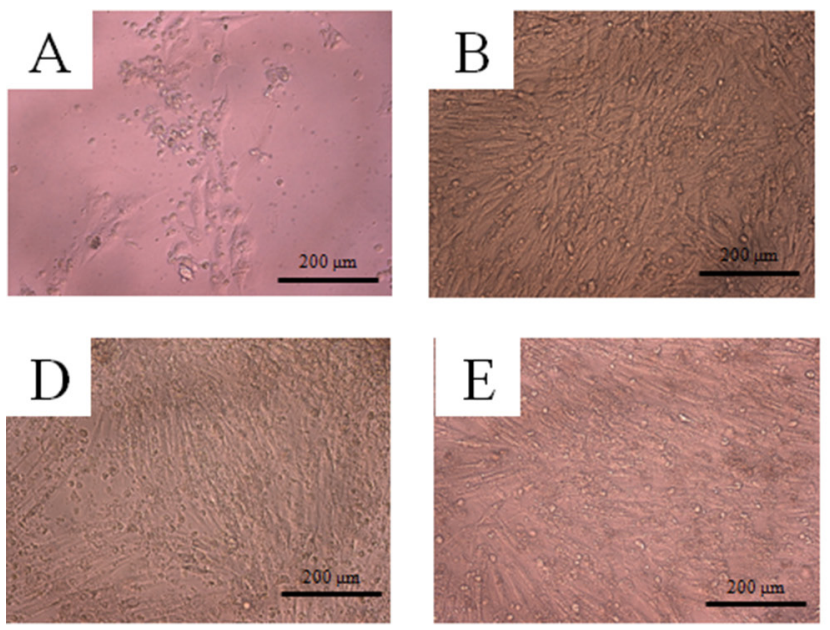

\section{Evaluation of secretion of human vascular endothelial growth factor}

The determination of human VEGF from 2- and 3-dimensional systems was performed using a commercially available kit (Quantikine ${ }^{\circledR}$ ELISA; R\&D Systems). All reagents and samples were prepared according to the manufacturer's recommendations. A media group served as the control.

\section{Statistical analysis}

A test of normality was performed with the Shapiro-Wilk test, and a one-way analysis of variance with Tukey's post hoc test was performed to analyze the differences between the groups, using a commercially available program (SPSS 12 for Windows; SPSS, Chicago, USA), with the level of significance set at 0.05 .

\section{Results}

\section{Evaluation of 2-dimensional culture}

The morphology of the osteoprecursor cells showed a fibroblast-like appearance on day 3 (Fig. 2A). No significant difference in the morphology was noted when the culture with gingiva-derived stem cells was at different ratios of stem cells to osteoprecursor cells: 1:3 (group 2), 2:2 (group 3), 3:1 (group 4), and 4:0 (group 5) (Fig. 2B, 2C, $2 \mathrm{D}$, and $2 \mathrm{E}$, respectively).

\section{Secretion of human vascular endothelial growth factor from 2-dimensional culture}

The secretion of VEGF was noted in groups 2, 3, 4, and 5 (Fig. 3), and it increased with the increase in stem cells. A statistically significant increase was noted in groups 3, 4 and 5 when compared with the media-only group $(\mathrm{p}<0.05)$.

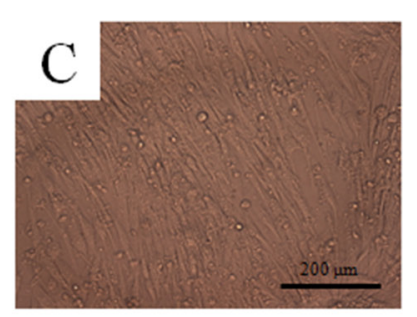

Fig. 2. Morphology of 2-dimensional stem cells cultured with osteoprecursor cells on day 3

A - group 1; B - group 2; C - group 3;

$D$ - group 4; E-group 5.

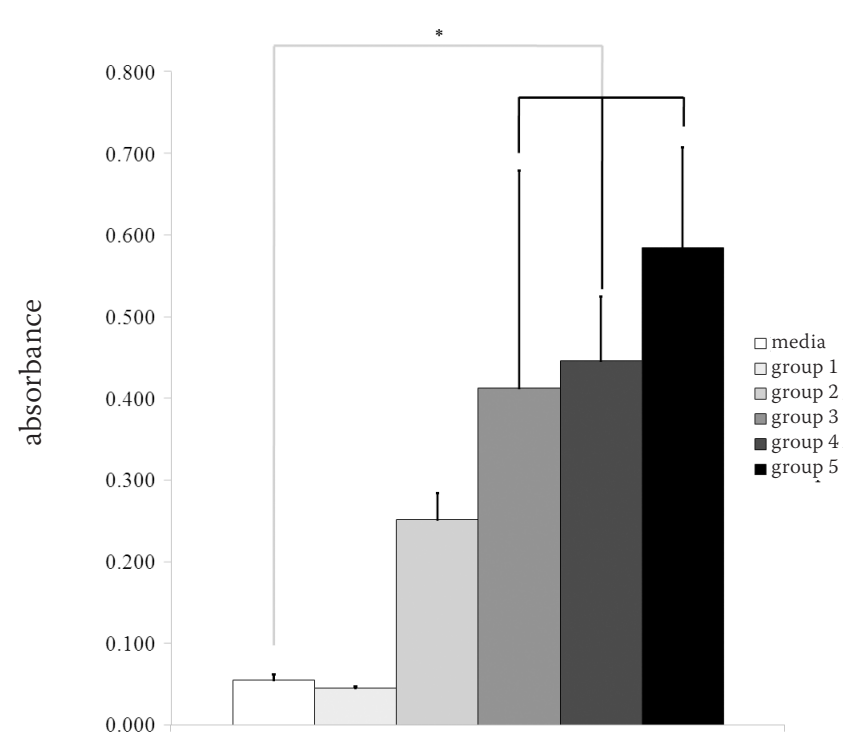

Fig. 3. Secretion of VEGF from 2-dimensional culture

One-way analysis of variance with Tukey's post hoc test was performed to determine the differences between the groups; ${ }^{*}$ statistically significant differences were noted when compared with the media-only group.

\section{Evaluation of spheroid morphology}

The morphology of the spheroids on day 3 is shown in Fig. 4. Osteoprecursor cells formed spheroids in concave microwells (Fig. 4A). Gingiva-derived stem cells and osteoprecursor cells also formed spheroids (Fig. 4B-E). No significant change in the morphology was noted with the increase in stem cells, at different ratios of stem cells to osteoprecursor cells: 1:3 (group 2), 2:2 (group 3), 3:1 (group 4), and 4:0 (group 5) (Fig. 4B, 4C, 4D, and 4E, respectively).

\section{Determination of cell viability and maintenance of expression of stem cell markers}

Most of the cells in the spheroids emitted green fluorescence; a small portion of red fluorescence was also noted (Fig. 5). Spheroids containing stem cells were positive for 

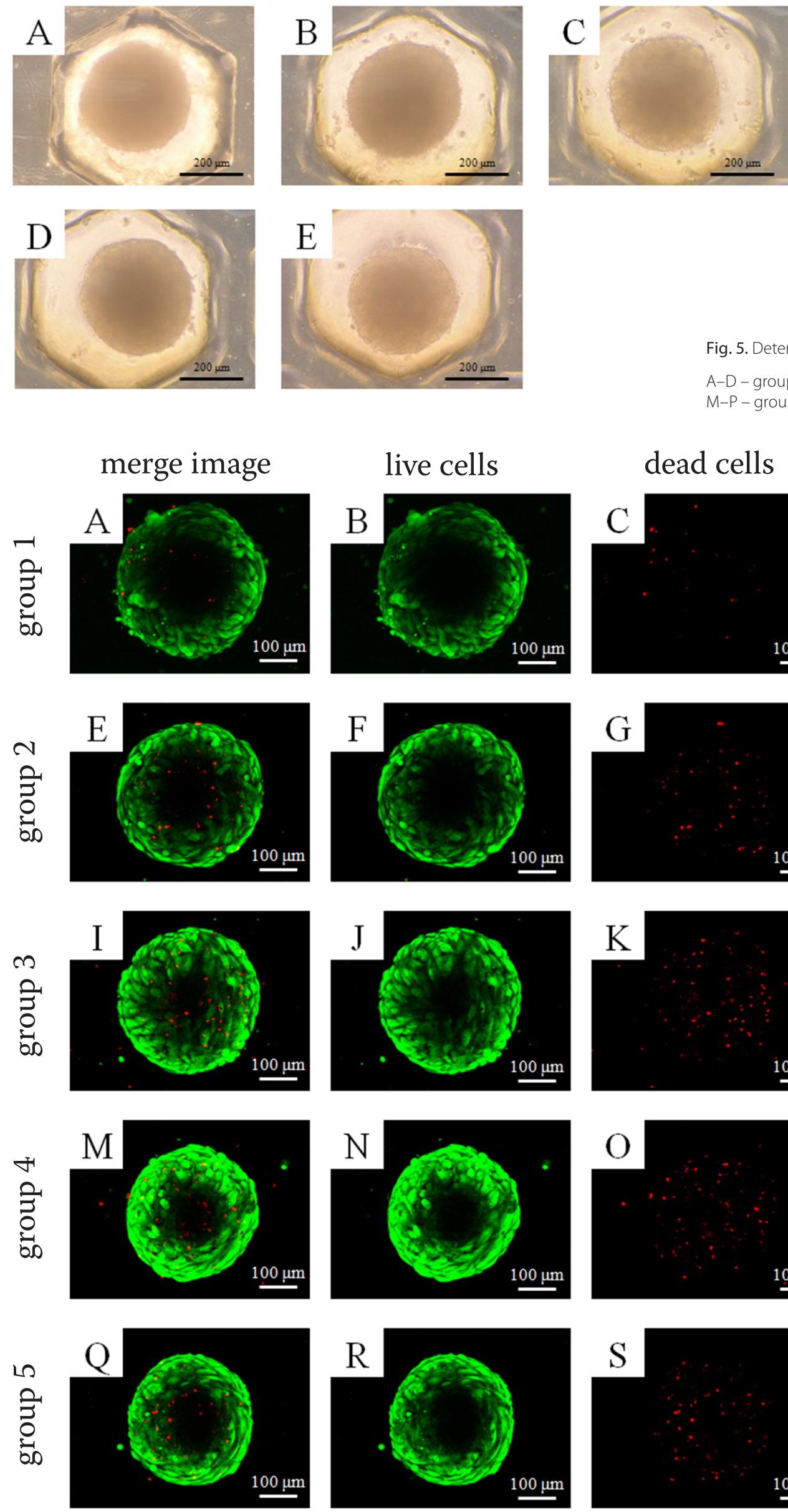

live cells

dead cells
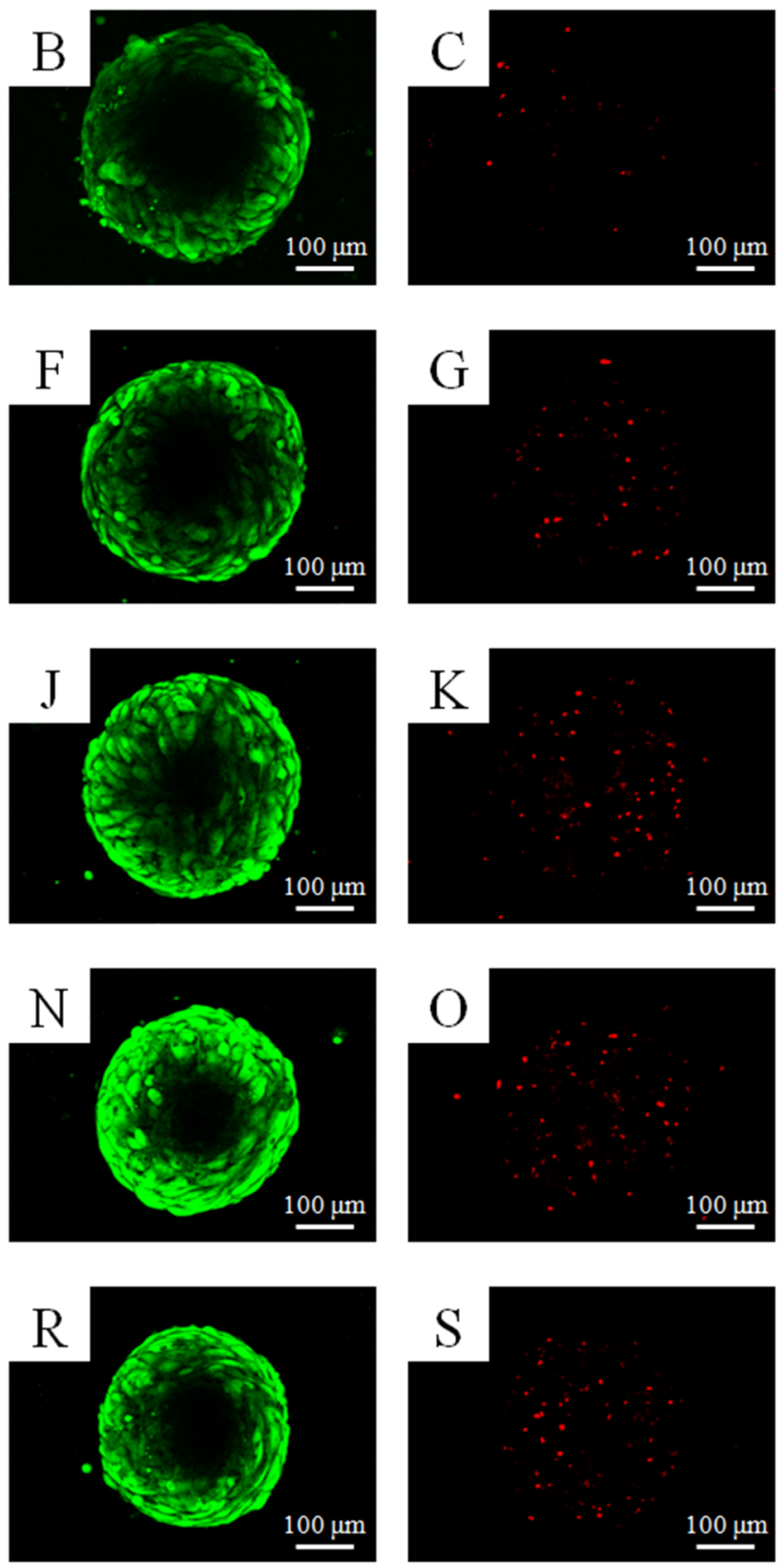
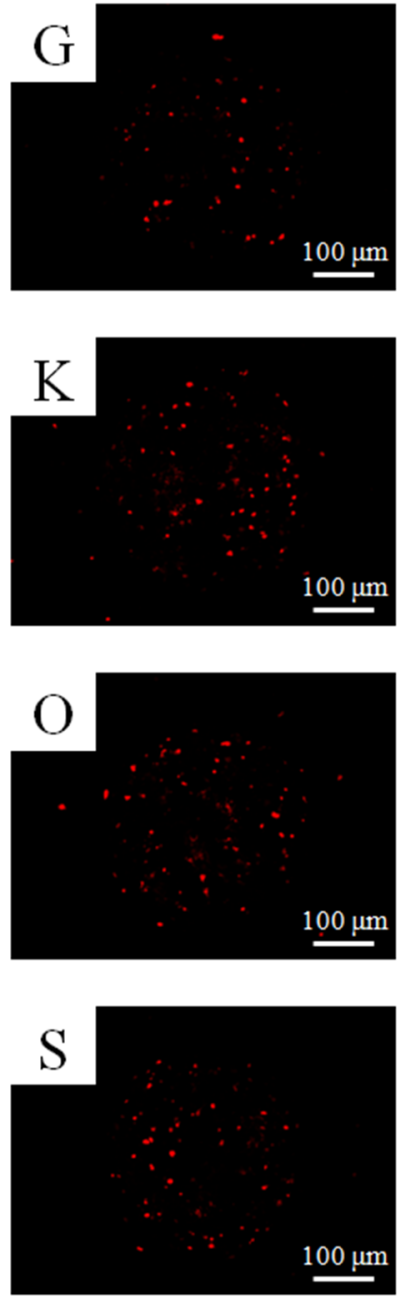

Fig. 4. Morphology of 3-dimensional stem cells cultured with osteoprecursor cells on day 3 (osteoprecursor cells formed spheroids in concave microwells) A - group 1; B - group 2; C - group 3; D - group 4; E - group 5; no significant change in the morphology was noted with the increase in stem cells, at different ratios of stem cells to osteoprecursor cells: 0:4, 1:3, 2:2, and 3:1.
Fig. 5. Determination of cell viability of cell spheroids A-D - group 1; E-H - group 2; I-L - group 3; $\mathrm{M}-\mathrm{P}$ - group $4 ; \mathrm{Q}-\mathrm{T}$ - group 5.
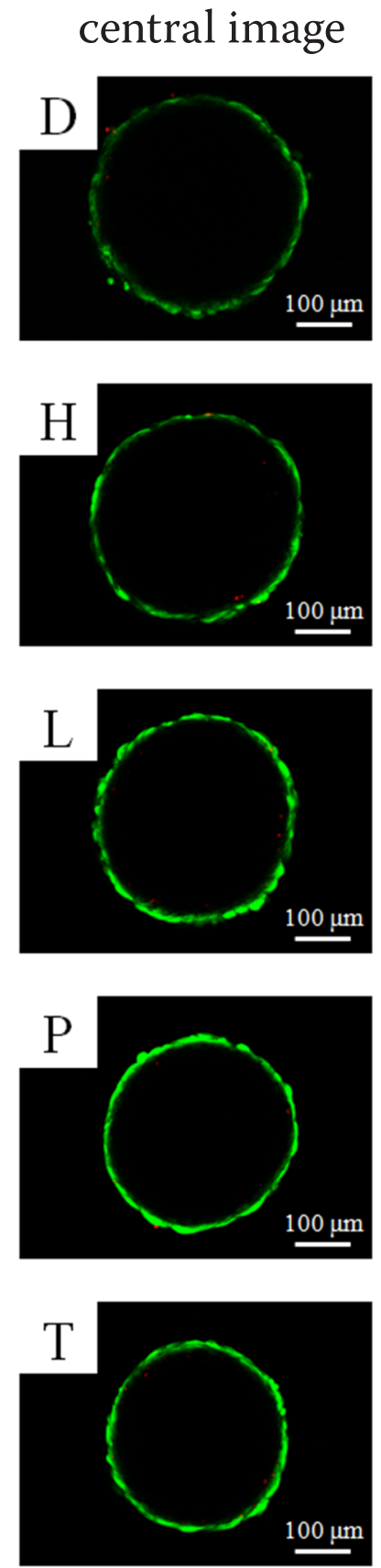

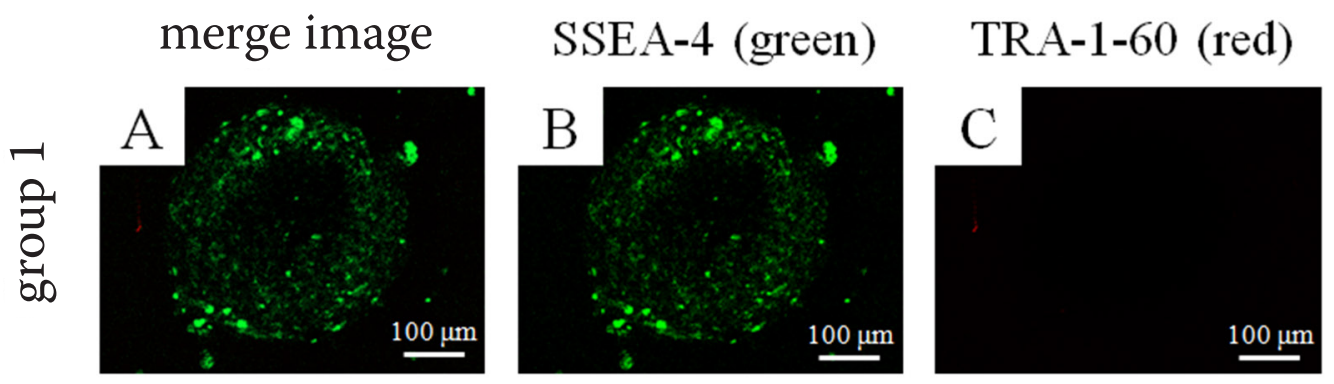

Fig. 6. Evaluation of maintenance of expression of stem cell markers of cell spheroids (spheroids containing stem cells were positive for the stem-cell markers SSEA-4)

A-C - group 1; D-F - group 2; G-I - group 3; J-L - group 4; $\mathrm{M}-\mathrm{O}$ - group 5.
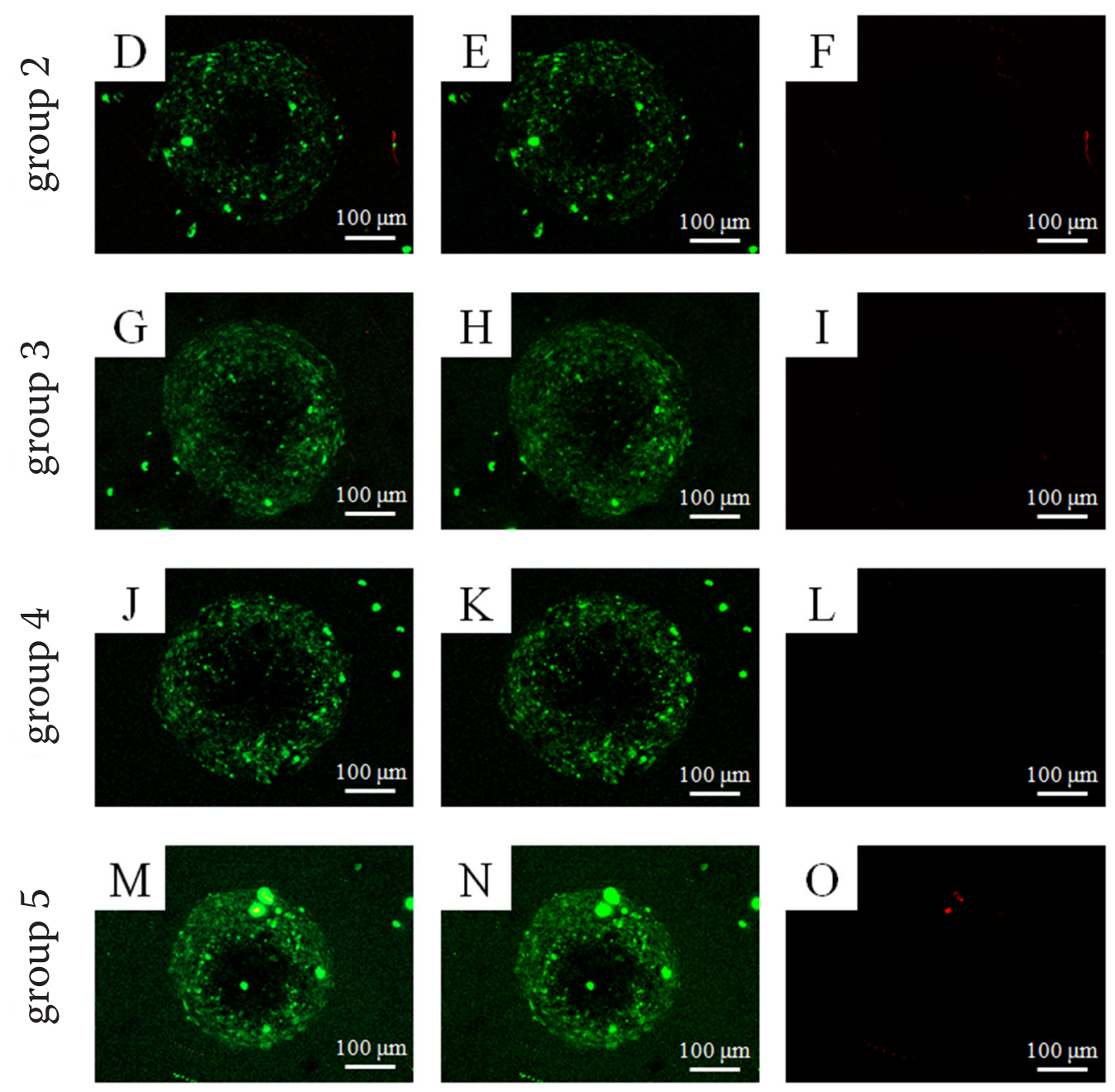

the stem-cell markers SSEA-4 and TRA-1-60(R) (Fig. 6). The green fluorescence showed a more intense assay with a higher number of stem cells.

\section{Secretion of human vascular endothelial growth factor from spheroids}

The secretion of VEGF from the spheroids was noted in groups 2, 3, 4, and 5 (Fig. 7), and it increased with the increase in the number of stem cells. A statistically significant increase in the secretion of VEGF was noted in groups 2, 3, 4 and 5 when compared with the mediaonly group $(\mathrm{p}<0.05)$.

\section{Discussion}

In this report, stem cell spheroids were fabricated using microwells, and the paracrine effects of the stem cell spheroids were evaluated. This study showed that cell spheroids formed with stem cells and osteoprecursor cells with different ratios, using microwells, had different paracrine effects on the stem cells. It also proved that the secretion of VEGF increased with the increase in stem cells.

More recently, it has been shown that the beneficial effects of stem cells were reported to come from both cell restoration and paracrine effects. ${ }^{5}$ Mesenchymal stem cells were reported to secrete a vast array of proteins, including growth factors, cytokines, chemokines, and extracellular 


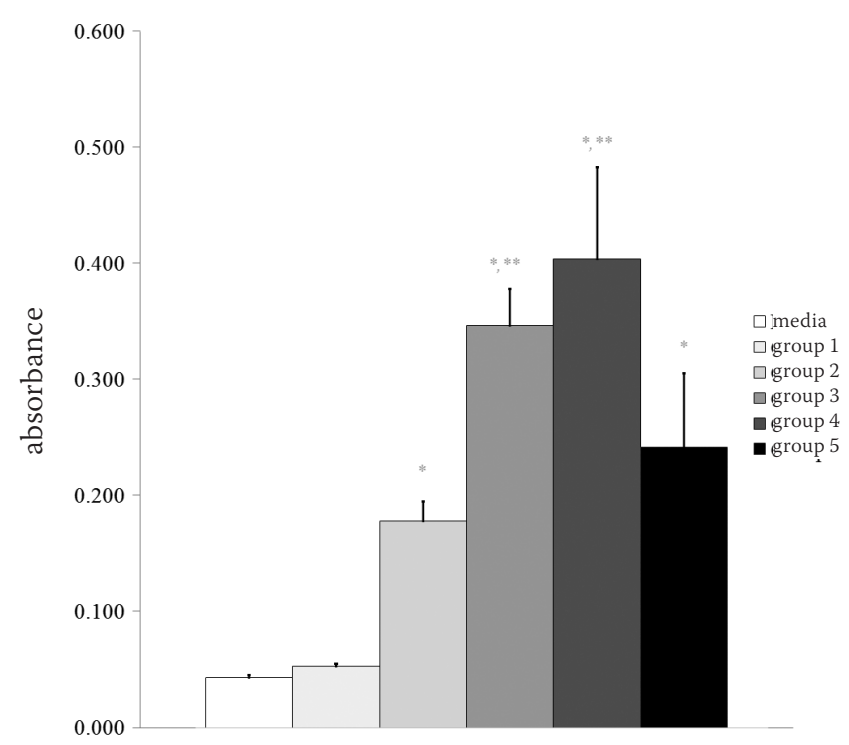

Fig. 7. Secretion of VEGF from cell spheroids

VEGF - vascular endothelial growth factor; differences between the groups were evaluated using a one-way analysis of variance with Tukey's post hoc test; ${ }^{*}$ statistically significant differences were noted when compared with the media-only group; ${ }^{* *}$ significant differences were seen when compared with group 2

matrix metalloproteinases. ${ }^{6}$ Various growth factors, e.g., vascular endothelial, fibroblast and hepatocyte growth factors, were secreted from mesenchymal stem cells, and previous reports showed that the growth of endothelial cells was stimulated by a conditioned medium of mesenchymal stem cells in a dose-dependent manner. ${ }^{7,8}$

Vascular endothelial growth factor is reported to be an important angiogenesis factor that mesenchymal stem cells release. ${ }^{9}$ It also regulates endothelial cell survival, differentiation and angiogenesis. ${ }^{10}$ The release of VEGF was demonstrated by the analysis of the mesenchymal stem cell-conditioned media. ${ }^{11}$ This study showed that mesenchymal stem cell-conditioned media enhanced the proliferation of endothelial stem cells in a dose-dependent manner, and anti-vascular endothelial growth factor antibodies partly attenuated this effect. This study clearly proved that the secretion of VEGF from 3-dimensional stem cell spheroids increased with the increase in stem cells. However, it should be noted that the different method of culturing mesenchymal stem cells and the variety of the paracrine factors may produce different results. ${ }^{6}$

The paracrine effects of stem cells may be applied for the treatment of various diseases. Stem cells from the vertebral body were reported to enhance the regeneration of the intervertebral disc by paracrine interaction. ${ }^{12}$ In a previous report, the transplanted stem cells released soluble factors that - acting in a paracrine fashion - contributed to cardiac repair and regeneration. ${ }^{13}$ Another report showed that adult neural stem cells exerted neuroprotective effects on cortical neurons following neurotoxic insult by paracrine effects. ${ }^{14}$ Adipose tissue-derived stem cells were applied for the treatment of erectile dysfunction due to the paracrine effect on surrounding tissues. ${ }^{15}$ The improvements of glucose intolerance were achieved from the factors secreted from dental pulp stem cells by increasing pancreatic $\beta$-cell function in streptozotocin-induced diabetic mice. ${ }^{16}$

This study applied a 3-dimensional culture system. In a previous study, 3-dimensional stem cell spheroids were generated from gingiva-derived stem cells with concave microwells. ${ }^{17}$ Recently, a 3-dimensional human stem cell construct has been built by applying bioprinting. ${ }^{18}$ A 3-dimensional stem cell system may extend the knowledge about the structure-function relationship. ${ }^{19}$ It was suggested that the 3-dimensional system simulates reality more closely when compared to the 2 -dimensional one. ${ }^{20}$ Additionally, it was suggested that 3-dimensional spheroids of mesenchymal stem cells showed enhanced survival effects. ${ }^{21}$

Stem cells may be obtained from bone marrow, peripheral blood, adipose tissue, and umbilical cord blood. ${ }^{22-25}$ Stem cells from bone marrow are widely applied, but this may have limitations due to the low number of stem cells, pain of extraction and morbidity. ${ }^{26,27}$ Umbilical cord blood may be a good source, but the supply is very limited. ${ }^{28}$ Stem cells can be also obtained from the oral and maxillofacial area, including the maxilla and mandible. ${ }^{29}$ The gingiva can be considered a favorable source of stem cells, because the tissue can be obtained from daily dental procedures under local anesthesia. ${ }^{3}$

This study showed that cell spheroids formed with stem cells and osteoprecursor cells with different ratios, using microwells, had paracrine effects on the stem cells. The secretion of VEGF increased with the increase in stem cells. This stem cell spheroid may be applied for tissue engineering purposes.

\section{References}

1. Wong SF, No da Y, Choi YY, Kim DS, Chung BG, Lee SH. Concave microwell based size-controllable hepatosphere as a three-dimensional liver tissue model. Biomaterials. 2011;32:8087-8096.

2. Jun Y, Kang AR, Lee JS, et al. 3D co-culturing model of primary pancreatic islets and hepatocytes in hybrid spheroid to overcome pancreatic cell shortage. Biomaterials. 2013;34:3784-3794.

3. Jin SH, Lee JE, Yun JH, Kim I, Ko Y, Park JB. Isolation and characterization of human mesenchymal stem cells from gingival connective tissue. J Periodontal Res. 2015;50:461-467.

4. Jin $\mathrm{SH}$, Kweon H, Park JB, Kim CH. The effects of tetracycline-loaded silk fibroin membrane on proliferation and osteogenic potential of mesenchymal stem cells. J Surg Res. 2014;192:1-9.

5. Baraniak PR, McDevitt TC. Stem cell paracrine actions and tissue regeneration. Regen Med. 2010;5:121-143.

6. Chan JK, Lam P. Soluble factors from human fetal bone marrowderived mesenchymal stem cells: Preparation of conditioned medium and its effect on tumor cells. Methods Mol Biol. 2016;1416:467475.

7. Liang X, Ding Y, Zhang Y, Tse HF, Lian Q. Paracrine mechanisms of mesenchymal stem cell-based therapy: Current status and perspectives. Cell Transplant. 2014;23:1045-1059.

8. Tang Y, Li Q, Meng F, et al. Therapeutic potential of HGF-expressing human umbilical cord mesenchymal stem cells in mice with acute liver failure. Int J Hepatol. 2016;2016:5452487. 
9. Yang $Y, \mathrm{Hu} S, \mathrm{Xu} \mathrm{X}$, et al. The vascular endothelial growth factorsexpressing character of mesenchymal stem cells plays a positive role in treatment of acute lung injury in vivo. Mediators Inflamm. 2016;2016:2347938.

10. Hoeben A, Landuyt B, Highley MS, Wildiers H, Van Oosterom AT, De Bruijn EA. Vascular endothelial growth factor and angiogenesis. Pharmacol Rev. 2004;56(4):549-580.

11. Kinnaird T, Stabile E, Burnett MS, et al. Local delivery of marrowderived stromal cells augments collateral perfusion through paracrine mechanisms. Circulation. 2004;109:1543-1549.

12. Shim EK, Lee JS, Kim DE, et al. Autogenous mesenchymal stem cells from the vertebral body enhance intervertebral disc regeneration by paracrine interaction: An in vitro pilot study. Cell Transplant. 2016; 25(10):1819-1832

13. Gnecchi M, Zhang Z, Ni A, Dzau VJ. Paracrine mechanisms in adult stem cell signaling and therapy. Circ Res. 2008;103:1204-1219.

14. Geranmayeh MH, Baghbanzadeh A, Barin A, et al. Paracrine neuroprotective effects of neural stem cells on glutamate-induced cortical neuronal cell excitotoxicity. Adv Pharm Bull. 2015;5:515-521.

15. Gokce A, Peak TC, Abdel-Mageed AB, Hellstrom WJ. Adipose tissuederived stem cells for the treatment of erectile dysfunction. Curr Urol Rep. 2016;17:14.

16. Izumoto-Akita T, Tsunekawa S, Yamamoto A, et al. Secreted factors from dental pulp stem cells improve glucose intolerance in streptozotocin-induced diabetic mice by increasing pancreatic beta-cell function. BMJ Open Diabetes Res Care. 2015;3:e000128.

17. Lee SI, Yeo SI, Kim BB, Ko Y, Park JB. Formation of size-controllable spheroids using gingiva-derived stem cells and concave microwells: Morphology and viability tests. Biomed Rep. 2016;4:97-101.

18. Gu Q, Tomaskovic-Crook E, Lozano R, et al. Stem cell bioprinting: Functional 3D neural mini-tissues from printed gel-based bioink and human neural stem cells. Adv Healthc Mater. 2016;5(12):1428.
19. Seo $\mathrm{S}, \mathrm{Na}$ K. Mesenchymal stem cell-based tissue engineering for chondrogenesis. J Biomed Biotechnol. 2011;2011:806891.

20. Valarmathi MT, Yost MJ, Goodwin RL, Potts JD. The influence of proepicardial cells on the osteogenic potential of marrow stromal cells in a threedimensional tubular scaffold. Biomaterials. 2008;29:2203-2216.

21. Xu Y, Shi T, Xu A, Zhang L. 3D spheroid culture enhances survival and therapeutic capacities of MSCs injected into ischemic kidney. J Cell Mol Med. 2016;20(7):1203-1213.

22. Zhu HX, Gao JL, Zhao MM, et al. Effects of bone marrow-derived mesenchymal stem cells on the autophagic activity of alveolar macrophages in a rat model of silicosis. Exp Ther Med. 2016;11:2577-2582.

23. Sheashaa $H$, Lotfy $A$, Elhusseini $F$, et al. Protective effect of adipose-derived mesenchymal stem cells against acute kidney injury induced by ischemia-reperfusion in Sprague-Dawley rats. Exp Ther Med. 2016;11:1573-1580.

24. Cui B, Li E, Yang B, Wang B. Human umbilical cord blood-derived mesenchymal stem cell transplantation for the treatment of spinal cord injury. Exp Ther Med. 2014;7:1233-1236.

25. Fu Q, Tang NN, Zhang Q, et al. Preclinical study of cell therapy for osteonecrosis of the femoral head with allogenic peripheral bloodderived mesenchymal stem cells. Yonsei Med J. 2016;57:1006-1015.

26. Sakaguchi Y, Sekiya I, Yagishita K, Muneta T. Comparison of human stem cells derived from various mesenchymal tissues: Superiority of synovium as a cell source. Arthritis Rheum. 2005;52:2521-2529.

27. Zuk PA, Zhu M, Ashjian $P$, et al. Human adipose tissue is a source of multipotent stem cells. Mol Biol Cell. 2002;13:4279-4295.

28. Fu L, Liu Y, Zhang D, Xie J, Guan H, Shang T. Beneficial effect of human umbilical cord-derived mesenchymal stem cells on an endotoxininduced rat model of preeclampsia. Exp TherMed. 2015;10:1851-1856.

29. Sunil P, Manikandhan R, Muthu M, Abraham S. Stem cell therapy in oral and maxillofacial region: An overview. J Oral Maxillofac Pathol. 2012;16:58-63. 